\title{
Effects of Planting Medium on the Propagation of Loquat (Eriobotrya japonica L.) from Cuttings and Seeds
}

\author{
Muhammad Imam Surya*, Lily Ismaini, Suluh Normasiwi \\ Research Center for Plant Conservation and Botanic Gardens, Indonesian Institute of Sciences (LIPI). Jl. Ir. H. Juanda No. 13 \\ Paledang, Bogor, 16122, West Java, Indonesia \\ * Corresponding Author. E-mail address: muhammad.imam.surya@lipi.go.id
}

\section{ARTICLE HISTORY:}

Received: 14 April 2021

Peer review completed: 14 September 2021 Received in revised form: 27 September 2021 Accepted: 4 October 2021

\section{KEYWORDS:}

\section{Cutting}

Eriobotrya japonica

Planting medium

Propagation

Seed

(C) 2021 The Author(s). Published by Department of Forestry, Faculty of Agriculture, University of Lampung in collaboration with Indonesia Network for Agroforestry Education (INAFE).

This is an open access article under the CC BY-NC license:

https://creativecommons.org/licenses/by$\mathrm{nc} / 4.0 \%$.

\begin{abstract}
Loquat (Eriobotrya japonica) has a great potential to be cultivated as a fruit crop in North Sumatra. In order to cultivate loquat, the availability of highquality seedlings is becoming an essential factor. This research was aimed to determine the response of loquat's seed, stem, and shoot cutting on various types of medium. The seed, stem, and shoots cutting of loquat were collected from North Sumatra. Three types of medium, i.e., humus + roasted rice husk (1:1), raw rice husk + sand (1:1), and humus + raw rice husk (1:1), were used during the experiment in Cibodas Botanical Garden. The results show that the highest percentage of seed germination on the $10^{\text {th }}$ week after planting was humus + roasted rice husk $(91.18 \%)$ and followed by humus + raw rice husk $(77.78 \%)$ and raw rice husk + sand $(69.44 \%)$. The combination of humus + roasted rice husk gave a significant effect on plant high $(9.178 \mathrm{a} \mathrm{cm})$, the number of leaves (5.51a), length of leaves (8.36a), and width of leaves (3.78a) on the $12^{\text {th }}$ week after planting. Moreover, there were no significant differences between shoot cutting and stem cutting propagation on parameters survival rate and the number of buds.
\end{abstract}

\section{Introduction}

Loquat or Biwa (Eriobotrya japonica L.) is a fruit plant with a high economic potential to develop in Indonesia. Loquat is the primary commodity of fruit crops in the tropics originating from China (Lin et al. 2007). In addition to China, currently, loquat has also become a major fruit commodity in Spain, Turkey, Pakistan, India, Italy, Brazil and has been cultivated in more than 30 countries, including Japan, Greece, Israel, the Mauritius Islands, the United States, Australia, Madagascar, New Zealand and South Africa (Badenes et al. 2000; Feng et al. 2007; Vilanova et al. 2001). The nutritional content and utilization of loquat as an economic value commodity have been reported in many studies. Loquat contains potent antioxidants (Marianne et al. 2018), sugars, vitamins, minerals, phenolic acids, and organic acids (Fu et al. 2011; Zhang et al. 2015). Loquat is a fruit plant that can be used directly or in processed form. The economic value of loquat is increased three times greater by making processed products compared to consumption of fresh fruit. Processed products from loquat fruit developed, such as jam, syrup, and fruit candy (Liu et al. 2016; Tian et al. 2007). On the other hand, loquat is used to treat hypoglycemia as a source of antioxidants, antiviral, antitumor, anti-inflammatory, cytotoxic, antimutagenic, and hypolipidemic 
activities (Baljinder et al. 2010). In addition, loquat extract is effective against cancer, chronic bronchitis, cough, and diabetes (Li et al. 2016).

In Indonesia, the loquat plant is reported to have naturalized in limited montane forests of Java and Sumatra (Kalkman 1993). Silalahi (2011) and Normasiwi et al. (2019) reported that loquat plants had been planted in several areas such as North Sumatra Province (Karo, North Tapanuli, Simalungun, Toba, Samosir, and Dairi), West Java (Cipanas), and North Sulawesi (Tondano). However, loquat cultivation is still done conventionally, so that the resulting product is not optimal and does not meet consumer demand.

Loquat plants can be propagated by seed, ducking, grafting, and cuttings. Research on the propagation of loquat variant $\mathrm{cv}$ Mardan through cuttings by immersing cuttings on growth regulators such as indole-3-butyric acid (IBA) and paclobutrazol (PBZ), resulted in a percentage of cuttings growth $40 \%$, propagation by grafting resulted in $70 \%$ of loquat seeds (Abbasi et al. 2014). Several vegetative and generative propagation efforts (Nasution et al. 2014; Surya et al. 2020; Tarigan and Barus 2014) and loquat cultivation (Tarigan et al. 2014) have been carried out in Indonesia but have not yet obtained satisfactory results. In general, if fruit plants are propagated through seeds, the characters or traits of the parents cannot be guaranteed to appear in the offspring, or it can be said that there will be a possibility of the emergence of different characters from the parents. The method of vegetative propagation ensures that the yield of the loquat produced will be the same as that of its parents. Khan et al. (2002) reported that plants that were propagated vegetatively would produce the same plants as their parents but were also influenced by the time of propagation, the season, and the method used. The vegetative propagation technique effectively produces stock with uniform crop production (Ismail et al. 2002). Seedlings of loquat fruit are also suitable for use as ornamental plants by using rootstocks that have grown well, then connected to scions that are ready to bear fruit to obtain relatively lower fruit plants.

The propagation of fruit trees is an important aspect of both seed and fruit production. Seeds that have high quality are strongly influenced by the mother plant and its propagation techniques. Furthermore, Hartman and Kester (2002) reported that no single mixed medium is ideal for seed production of all types of plants. The propagation medium used in horticulture and forestry cultivation consists of a mixture of organic and inorganic components with different but complementary properties. The appropriate propagation medium depends on the species, the type of propagation, the season, and the propagation system. In addition, most loquat orchards are built using seed, grafting, and shoot cutting. It is due to the unavailability of certified seeds and a lack of information about cultivation technology. In North Sumatra, as one of the centers for loquat cultivation, information regarding production technology for high-quality seeds is still quite limited. This study aims to determine the effect of planting medium for the propagation of loquat seeds through cuttings and seeds.

\section{Materials and Methods}

This research was conducted at the experimental greenhouse of Cibodas Botanical Gardens, Indonesian Institute of Sciences (LIPI) from April-July 2018. All planting materials in the form of cuttings and seeds were obtained from exploring loquat plants cultivated in the Lake Toba area, namely Tobasa, Samosir, Simalungun, Dairi, and Karo Regencies, North Sumatra. The research location was at an altitude range of 991-1523 masl, soil pH of 5-7, and relative humidity of $50-80 \%$. There were three types of plant material used in this experiment, including seeds, 
stem cuttings, and shoot cuttings (Fig. 1). Planting medium treatment was a combination of humus, sand, raw rice husk, and roasted rice husk combined with a ratio of 1:1 in each medium combination. The equipment used in this experiment includes polybags, shovels, rulers, and stationery.
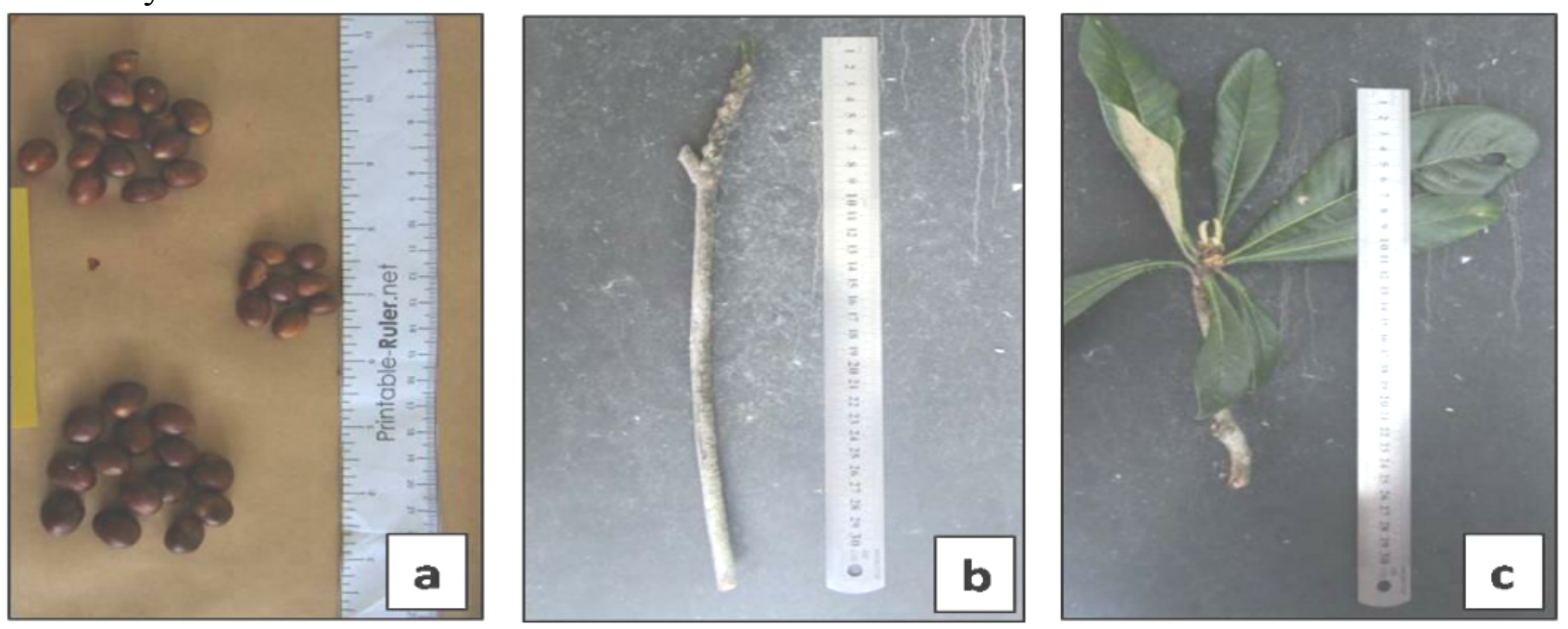

Fig. 1. Type of propagation material used (a) seeds, (b) stem cuttings, (c) shoot cuttings.

\subsection{Research Implementation}

\subsubsection{Seed Propagation}

The seeds used for plant material came from 5 research locations in the Toba area, namely Tobasa, Samosir, Simalungun, Dairi, and Karo Regencies. Then, the seeds obtained from the ripe fruit were cleaned of the pulp (Fig. 1a), dried, and planted in various combinations of growing medium. This study was arranged using a completely randomized design, with three types of combination medium treatment, namely humus + roasted rice husk $(1: 1)$, raw rice husk + sand (1:1), and humus + raw rice husk (1:1) and seven replicates times where each replicated five experimental units (the minimum number of seeds used was 35 seeds per treatment). The observed growth parameters included plant height, number of leaves, leaf length, leaf width, number of shoots, percentage of germination. The observation process was carried out up to 12 weeks after planting (WAP).

\subsubsection{Cuttings Propagation}

Plant material (shoot cuttings and stem cuttings) came from 5 research locations in the Toba area, namely Tobasa, Samosir, Simalungun, Dairi, and Karo Regencies. The stem cuttings used as material were $30 \mathrm{~cm}$ long with two buds (Fig. 1b), while the shoot cuttings used were $20 \mathrm{~cm}$ long and free of pests and diseases (Fig. 1c). In the shoot cutting material, 3-5 leaves are left. Before planting, shoot cuttings and stem cuttings were soaked in a root stimulant solution (Rootone F) for 15 minutes, then the cuttings were planted in three types of combination medium, namely humus + roasted rice husk (1:1), raw rice husk + sand (1:1), and humus + raw rice husk (1:1). The experiment was arranged using a randomized block design with ten repetitions in each experimental unit. Grouping is done based on the material used. Parameters observed included growth percentage and number of shoots. Observations were made at four and eight weeks after planting (WAP). 


\subsection{Data Analysis}

The data obtained were analyzed using analysis of variance. If there is a significant difference, then it is continued with the Honestly Significant Difference (HSD) test to find out which treatments have the same or different effects from one another. The software used for data analysis was SPSS 16.

\section{Results and Discussion}

Differences in sources of plant material in propagation efforts are factors that affect the production process and the quality of plant seeds. Therefore, two experiments were carried out in this study, namely generative propagation of loquat through seeds and vegetatively through the stem and shoot cuttings.

\subsection{Seed Propagation}

Based on the results of the trial of loquat seed germination in three different mediums, it was seen that the highest germination of loquat seeds at $10^{\text {th }}$ week was indicated by the combination of humus + roasted rice husk at $91.18 \%$, followed by a combination of humus + raw rice husk at $77.78 \%$ and raw rice husk + sand by $69.44 \%$ (Fig. 2). These results indicate a significant difference in the germination percentage value with the experiment of seed propagation by Nasution et al. (2014), where the effort of soaking the seeds with animal urine and cutting the seeds did not significantly affect the percentage of germination, with an average germination rate of $41.67-70.83 \%$. Furthermore, from the experimental results, it is known that the best growing medium for seeds derived from seeds is a combination of humus and roasted rice husk (Fig. 3). It is indicated by the results of observations on the parameters of plant height, the number of leaves, leaf width, and leaf length at $8^{\text {th }}$ and $12^{\text {th }}$ week (Table 1). The combination of humus and roasted rice husk medium significantly affected plant height, leaf number, leaf width, and leaf length, with the highest average plant height being $9.18 \mathrm{~cm}$, leaf number 5.51 , leaf number length $8.37 \mathrm{~cm}$, and leaf width $3.78 \mathrm{~cm}$ at $12 \mathrm{WAP}$.

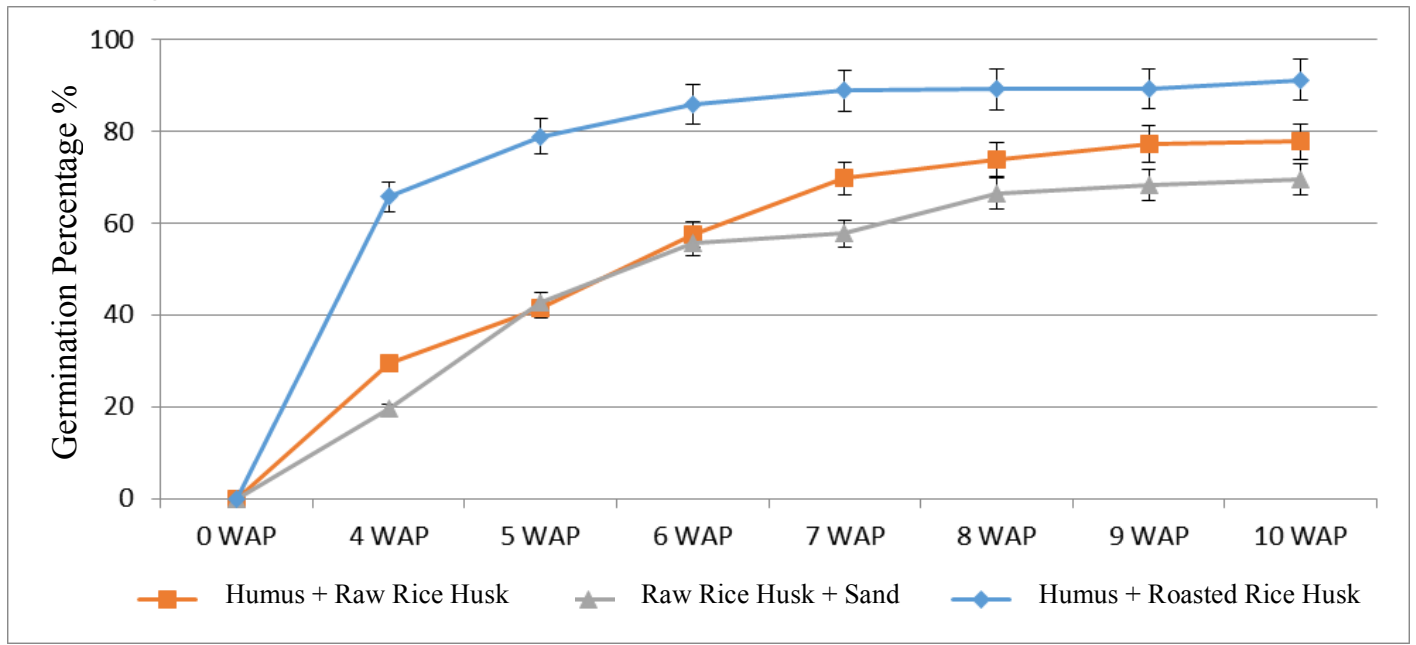

Fig. 2. Average percentage germination of loquat (E. japonica) seeds in three different medium types. 


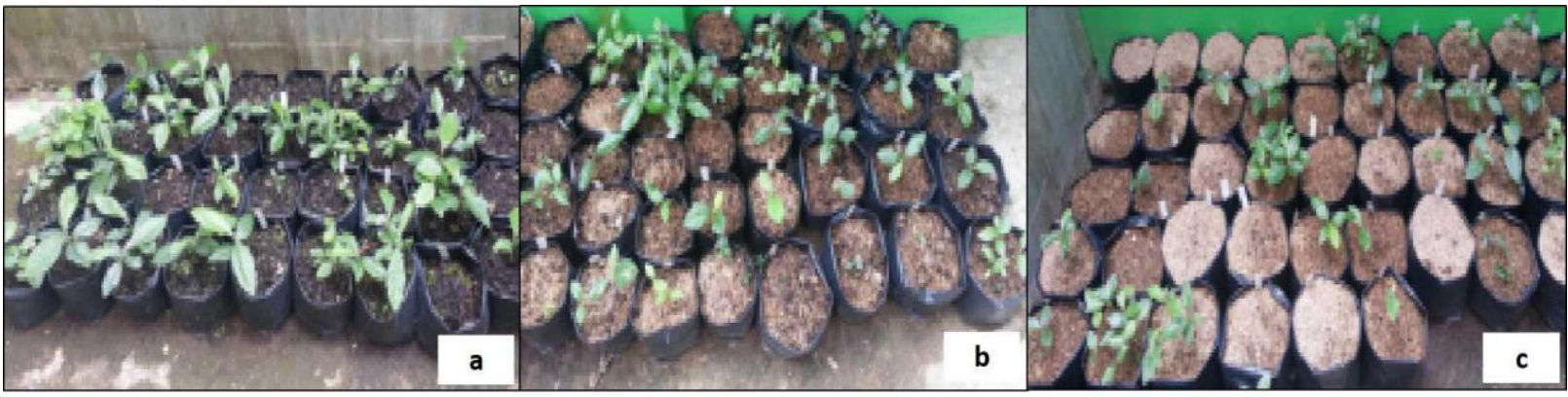

Fig. 3. Germination of loquat (E. japonica) seeds on (a) humus + roasted rice husk, (b) humus + raw rice husk, (c) raw rice husk + sand at 12 weeks after planting (WAP).

Table 1. Seedling growth of the loquat (E. japonica) derived from seeds

\begin{tabular}{|c|c|c|c|c|c|}
\hline Time & Medium & $\begin{array}{l}\text { Plant Height } \\
\text { (cm) }\end{array}$ & $\begin{array}{c}\text { Leaves } \\
\text { Number } \\
\text { (sheet) }\end{array}$ & $\begin{array}{c}\text { Leaves } \\
\text { Length } \\
(\mathrm{cm})\end{array}$ & $\begin{array}{l}\text { Leaves } \\
\text { Width } \\
\text { (cm) }\end{array}$ \\
\hline \multirow{3}{*}{8 WAP } & $\begin{array}{l}\text { Humus + Raw } \\
\text { Rice Husk }\end{array}$ & $5.81^{\mathrm{a}} \pm 1.68$ & $2.97^{\mathrm{b}} \pm 1.06$ & $5.50^{\mathrm{a}} \pm 1.80$ & $2.72^{\mathrm{a}} \pm 0.96$ \\
\hline & $\begin{array}{c}\text { Raw Rice Husk }+ \\
\text { Sand }\end{array}$ & $6.01^{\mathrm{a}} \pm 1.64$ & $2.68^{\mathrm{b}} \pm 0.81$ & $5.58^{\mathrm{a}} \pm 1.71$ & $2.75^{\mathrm{a}} \pm 0.82$ \\
\hline & $\begin{array}{c}\text { Humus + Roasted } \\
\text { Rice Husk }\end{array}$ & $6.61^{\mathrm{a}} \pm 1.74$ & $3.82^{\mathrm{a}} \pm 0.80$ & $6.51^{\mathrm{a}} \pm 1.48$ & $3.12^{\mathrm{a}} \pm 0.82$ \\
\hline \multirow{3}{*}{$12 \mathrm{WAP}$} & $\begin{array}{l}\text { Humus + Raw } \\
\text { Rice Husk }\end{array}$ & $6.16^{\mathrm{b}} \pm 1.68$ & $3.90^{\mathrm{b}} \pm 1.09$ & $5.75^{\mathrm{b}} \pm 1.71$ & $2.80^{\mathrm{b}} \pm 0.83$ \\
\hline & $\begin{array}{c}\text { Raw Rice Husk }+ \\
\text { Sand }\end{array}$ & $6.06^{\mathrm{b}} \pm 1.67$ & $3.31^{\mathrm{b}} \pm 0.79$ & $5.91^{\mathrm{b}} \pm 1.64$ & $2.90^{\mathrm{b}} \pm 0.76$ \\
\hline & $\begin{array}{c}\text { Humus + Roasted } \\
\text { Rice Husk }\end{array}$ & $9.18^{a} \pm 2.47$ & $5.51^{\mathrm{a}} \pm 1.32$ & $8.32^{\mathrm{a}} \pm 2.87$ & $3.78^{\mathrm{a}} \pm 1.03$ \\
\hline
\end{tabular}

Notes: WAP= weeks after planting; Numbers followed by different letters in the same column and time show significantly different results at the 5\% HSD test level.

The results showed that the best growing mediums for seeds derived from seeds were a combination of humus and roasted rice husks. The combination of humus and roasted rice husk medium significantly increased plant height, the number of leaves, leaf length, and leaf width at 12 WAP. Based on the results of this experiment, it was known that the combination of humus and roasted rice husks was able to meet the criteria for an excellent growing medium for loquat seeds propagated through seeds. Roasted rice husk has light and coarse characteristics so that air circulation is high, the ability to hold water is high, and it is black to absorb sunlight well. Gusmailina and Pari (2003) reported that the addition of roasted rice husk in the growing medium could also improve soil properties, including making fertilization more effective, improving soil physical properties (porosity and aeration), binding nutrients (when excess nutrients) that plants can use when nutrient deficiency, released slowly according to the needs of the plant. Supriyanto and Fiona (2010) stated that the addition of roasted rice husk in the growing medium has a significant effect on the height growth of Jabon seedlings, the addition of roasted rice husk can increase the height growth of Jabon seedlings by $18.31-28.36 \%$. In addition, Kurniastuti et al. (2017) reported that the interaction between rice husk charcoal or ash with the addition proportion 
could increase lateral root length but could not increase dry shoot weight and root dry weight. Factors of root growth affection are the presence of soil pores. Soil pores are spaces that can be penetrated by roots and contain air for root respiration. Lateral roots increase in length due to the gaps formed in addition to soil enhancers such as roasted rice husk in various proportions. In general, each species has an optimum germination medium that is not the same. It is consistent with several studies showing that the best medium for germination of each species is different, such as topsoil mixed with sand (1:1) for Hevea brasiliensis seeds (Bahri and Saukani 2017), soil medium mixed with manure and roasted rice husk (2:1:1) on Carica papaya seeds (Imanda and Suketi 2018), soil medium mixed with manure and roasted rice husk (1:1:1) on Coffea arabica seeds (Taryana and Sugiarti 2019). Furthermore, the medium used for plant propagation has several requirements, namely compact enough (firm and dense) to be strong enough to support upright stems, water holding capacity is good enough for its development (Hartman and Kester 2002), and not too humid because it will stimulate the growth of fungi that can cause disease (Lakitan 1995).

\subsection{Cuttings Propagation}

Propagation efforts using shoot cuttings and stem cuttings have been carried out using three types of combinations of growing medium (Fig. 4). Statistically, the results indicated that there was no significant difference in the medium treatment for the growth of shoot cuttings and stem cuttings of loquat plants, both in viability and number of shoots.

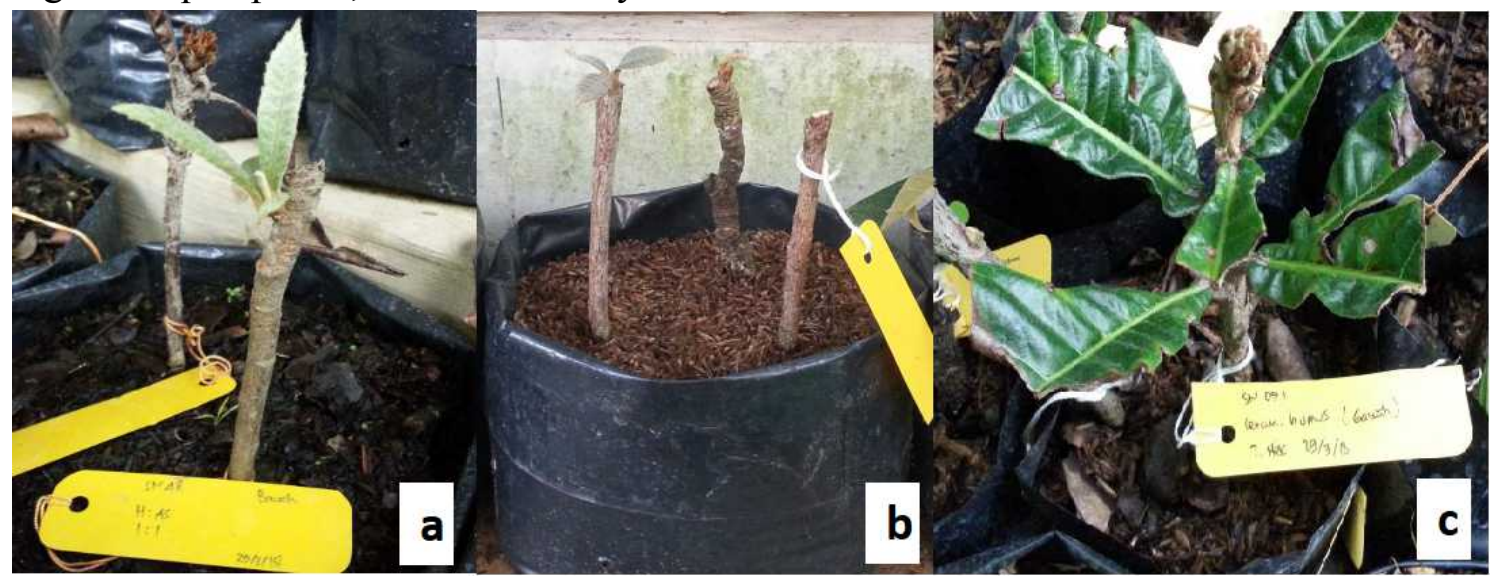

Fig. 4. Growth of stem cuttings and shoot cuttings (E. japonica) on (a) humus + roasted rice husk, (b) raw rice husk + sand, (c) humus + raw rice husk.

The results showed that the medium with the highest value for the propagation of loquat seedlings through shoot cuttings with a raw rice husk + sand medium combination. It can be seen in the percentage of viability of $40 \%$ and the average number of shoots of 0.25 at eight weeks after planting (Table 2). Furthermore, the combination of humus + roasted rice husk medium in loquat propagation through stem cuttings had the best percentage of viability of $87.5 \%$. At the same time, the highest number of shoots was shown by the combination of raw husk + sand medium, which was 1.57 shoots at eight weeks after planting.

The results showed that the mediums had the highest average value for the propagation of loquat seedlings through shoot cuttings was a combination of raw rice husk + sand medium. The combination of raw rice husk + sand medium supported shoot cuttings well and prevented shoot rot from providing a good percentage of growth on loquat shoot cuttings. Suprapto (2014) 
reported that shoot growth on cuttings is supported by internal factors, including the genetic and innate traits of the cuttings themselves, then the most dominant is influenced by external factors, namely planting medium, temperature, and humidity. Sand has porous physical properties that facilitate water and air circulation in the soil (Aldi et al. 2017), while rice husk is a light-medium, has good water absorption capacity and does not affect $\mathrm{pH}$, and does not contain nutrients and salt solutions (Marlina and Rusnandi 2007).

Table 2. Growth of loquat (E. japonica) seedlings from vegetative propagation

\begin{tabular}{|c|c|c|c|c|c|}
\hline \multirow[b]{2}{*}{$\begin{array}{l}\text { Type of } \\
\text { Samples }\end{array}$} & \multirow[b]{2}{*}{ Medium } & \multicolumn{2}{|c|}{ Four weeks after planting } & \multicolumn{2}{|c|}{ Eight weeks after planting } \\
\hline & & $\begin{array}{c}\text { Plant } \\
\text { survival } \\
\text { rate }(\%)\end{array}$ & $\begin{array}{l}\text { Shoots } \\
\text { Number }\end{array}$ & $\begin{array}{c}\text { Plant } \\
\text { survival rate } \\
(\%)\end{array}$ & $\begin{array}{l}\text { Shoots } \\
\text { Number }\end{array}$ \\
\hline \multirow{3}{*}{$\begin{array}{c}\text { Shoot } \\
\text { cuttings }\end{array}$} & Raw Rice Husk + Sand & $40 \mathrm{a}$ & $0 \mathrm{a}$ & $40 \mathrm{a}$ & $0.250 \mathrm{a}$ \\
\hline & Humus + Roasted Rice Husk & $37.5 \mathrm{a}$ & $0 \mathrm{a}$ & $18.7 \mathrm{a}$ & $0 \mathrm{a}$ \\
\hline & Humus + Raw Rice Husk & $40 \mathrm{a}$ & $0 \mathrm{a}$ & $10 \mathrm{a}$ & $0 \mathrm{a}$ \\
\hline \multirow{3}{*}{$\begin{array}{c}\text { Stem } \\
\text { Cuttings }\end{array}$} & Raw Rice Husk + Sand & $70 \mathrm{a}$ & $1.143 \mathrm{a}$ & $70 \mathrm{a}$ & $1.571 \mathrm{a}$ \\
\hline & Humus + Roasted Rice Husk & $87.5 \mathrm{a}$ & $1.385 \mathrm{a}$ & $87.5 \mathrm{a}$ & $1.214 \mathrm{a}$ \\
\hline & Humus + Raw Rice Husk & $80 \mathrm{a}$ & $1.375 \mathrm{a}$ & $70 \mathrm{a}$ & $1.285 \mathrm{a}$ \\
\hline
\end{tabular}

Notes: Numbers followed by the same letter in the same column simultaneously show results that are not significantly different at the 5\% HSD test level.

On the other hand, the combination of humus + roasted rice husk was the best medium for the growth of loquat plants from stem cuttings. Humus medium and roasted rice husk have the advantage of being used as planting material. Humus is a planting material rich in organic matter, can increase the capacity of groundwater and soil aeration, and can decompose toxic organic compounds (Kurniawan et al. 2016). Roasted rice husk has good aeration that can improve the physical and chemical structure of the soil, and the process of burning rice husk will produce a sterile medium that can protect plants from plant growth-disturbing pathogens (Gustia 2013). Suharsi and Andriani (2013) stated that the composition of roasted rice husk, soil, and compost of 2:2:1 is the best medium to stimulate Sansevieria leaf shoot cuttings.

\section{Conclusions}

The planting medium significantly affects the percentage of loquat seed germination. The best medium for the propagation of loquat seeds through seeds is the humus + roasted rice husk medium, with a growth percentage of $91.18 \%$. For propagation through shoot cuttings and stem cuttings, the combination of planting medium used did not show a significant difference in yield. However, the highest average value for the growth of shoot cuttings was shown by the combination of raw rice husk + sand medium (40\%), while for stem cuttings, it was a combination of humus + roasted rice husk medium (87.5\%). Based on the results of this study, for the fulfillment of loquat seeds, it can be recommended propagation through seeds or stem cuttings.

\section{Acknowledgments}

The authors would like to thank the field team that helped with the samples collection for this study. This study was supported by Research Center for Biology LIPI through IBSAP Grant in $2019 / 2020$. 


\section{References}

Abbasi, N.A., Hafiz, I.A., Qureshi, A.A., Ali, I., and Mahmood, S.R. 2014. Evaluating the Success of Vegetative Propagation Techniques in Loquat cv. Mardan. Pakistan Journal of Botani 46(2): 579-584.

Aldi, Muhardi., and Lasmini, S.A. 2017. Pertumbuhan Stek Tanaman Lada (Piper nigrum Linn) pada Komposisi Medium Tumbuh dan Dosis Air Kelapa yang Berbeda. Agrotekbis 5(4): 415-422.

Badenes, M. L., Martines-Calvo, J., and Liacer, G. 2000. Analysis of Germplasm Collection of Loquat (Eriobotrya japonica Lindl.). Euphytica 114: 187-194. DOI: 10.1023/A:1003950215426

Bahri, S., and Saukani, S. 2017. Pengaruh Ukuran Biji dan Medium Tanam terhadap Perkecambahan dan Pertumbuhan Bibit Karet (Hevea brasiliensis Muell. Arg.). Jurnal Penelitian Agrosamudra 4(1): 58-70.

Baljinder, S., Seema, G., Dharmendra, K., Vikas, G., and Parveen, B. 2010. Pharmacological Potential of Eriobotrya japonica - an Overview. International Research Journal of Pharmacy 1(1): 95-99.

Feng, J. J., Liu, Q., Wang, X. D., Chen, J. W., and Ye, J. G. 2007. Characterization of a New Loquat Cultivar 'Ninghaibai'. Acta Horticulturae 750: 117-124. DOI: 10.17660/ActaHortic.2007.750.16

Fu, X., Kong, W., Peng, G., Zhou, J., Azam, M., Xu, C., and Chen, K. 2011. Plastid Structure and Carotenogenic Gene Expression in Red-and White-Fleshed Loquat (Eriobotrya japonica) Fruits. Journal of Experimental Botany 63: 341-354. DOI: 10.1093/jxb/err284

Gusmailina, G., and Pari, S. K. 2003. Pengembangan Penggunaan Arang untuk Rehabilitasi Lahan. Buletin Penelitian dan Pengembangan Kehutanan 4(1): 21-30.

Gustia, H. 2013. Pengaruh Penambahan Sekam Bakar Pada Medium Tanam Terhadap Pertumbuhan dan Produksi Tanaman Sawi (Brassica juncea L.). E-journal Widya Kesehatan dan Lingkungan 1(1): 12-17.

Hartman, H. T, and Kester, D. E. 2002. Plant Propagation: Principles and Practices. Seventh Edition. Prentice-Hall, New Jersey.

Imanda, N., and Suketi, K. 2018. Pengaruh Jenis Medium Tanam terhadap Pertumbuhan Bibit Pepaya (Carica papaya L.) Genotipe IPB 3, IPB 4, dan IPB 9. Buletin Agrohorti 6(1):101113.

Ismail, P., Shamsudin, I., and Mohd, N. H. 2002. Challenges of Peat Swamp Forest Rehabilitation: A Case Study in North Selangor, Peninsular Malaysia. Paper Presented at MSTC 2002, 17-19.

Kalkman, C. 1993. Rosaceae. Flora Malesiana I. p. 227-351.

Karadeniz, T. 2003. Investigations on Anatomical and Histological Development of Chip Budding and Tongue Grafts in Loquat (Eriobotrya japonica Lindl.). In: Llácer G. (ed.), Badenes M.L. (ed.). First international symposium on loquat. Zaragoza. p. 75-78.

Khan, A. R., Imran, M., and Chattha, G. A. 2002. Propagation Trials in Loquat (Eriobotrya japonica L.). Pakistan Journal of Agricultural Research 17(2): 197-198.

Kurniastuti, T., Puspitorini, P., and Punjungsari, T. N. 2017. Pengaruh Penambahan Abu Sekam Padi (Rice Husk Ash) dengan Proporsi Berbeda terhadap Pertumbuhan Selada air (Lactuca sativa L.). Journal Viabel Pertanian 11(2): 1-8. DOI: 10.35457/viabel.v11i2.369 
Kurniawan, B., Suryanto, A., and Maghfoer, M. D. 2016. Pengaruh Beberapa Macam Medium Terhadap Pertumbuhan Stek Plantlet Tanaman Kentang (Solanum tuberosum L.) Varietas Granola Kembang. Jurnal Produksi Tanaman 4(2): 123-128.

Lakitan, B. 1995. Fisiologi Pertumbuhan dan Perkembangan Tanaman. Raja Grafinda Persada, Jakarta.

Li, X., Xu, C., and Chen, K. 2016. Nutritional Composition of Fruit Cultivars: Loquat (Eriobotrya japonica Lindl.). In: Nutritional Composition of Fruit Cultivars. Academic, San Diego.

Lin, S., Huang, X., Cuevas, J., and Janick, J. 2007. Loquat: An Ancient Fruit Crop with a Promising Future. Chronica Horticulturae 47(2): 12-15.

Liu, Y., Zhang, W., Xu, C., and Li, X. 2016. Biological Activities of Extracts from Loquat (Eriobotrya japonica Lindl.): A Review. International Journal of Molecular Sciences 17(12): 1-15. DOI: 10.3390/ijms 17121983

Marianne, M., Septiani, R., and Yuliana, Y. 2018. Aktivitas Antioksidan Ekstrak Etanol Daun Biwa (Eriobotrya japonica (Thunb.) Lindl.) terhadap DPPH (1, 1-diphenyl-2picrylhydrazyl). Talenta Conference Series: Tropical Medicine 1(3): 86-89. DOI: 10.32734/tm.v1i3.267

Marlina, N., and Rusnandi, D. 2007. Teknik Aklimatisasi Planlet Anthurium pada Beberapa Medium Tanam. Buletin Teknik Pertanian 12(1): 38-40.

Nasution, L. W., Barus, A., Mawarni, L., and Tarigan, R. 2014. Perkecambahan dan Pertumbuhan Bibit Biwa (Eriobotrya japonica Lindl.) Akibat Perendaman pada Urin Hewan dan Pemotongan Benih. Jurnal Online Agroekoteknologi 2(4): 1367-1375.

Normasiwi, S., Ismaini, L., and Surya, M. I. 2019. Inventarisasi dan Studi Ekologi Buah Biwa (Eriobotrya japonica Lindl.) di Lima Kabupaten di Sumatera Utara. Al-Kauniyah: Jurnal Biologi 12(2): 189-197. DOI: 10.15408/kauniyah.v12i2.10917

Silalahi, F. H., Marpaung, A. E., and Tarigan, R. 2011. Tanggapan Pertumbuhan Tanaman Biwa terhadap Berbagai Perbandingan Dosis Pupuk N, P, dan K. Jurnal Hortikultura 21(1): 113. DOI: $10.21082 /$ jhort.v21n1.2011.p1-13

Suharsi, T. K., and Andriani, N. 2013. Pertumbuhan Tunas Sansevieria trifaciata Plain'Lanrentii' Pada Beberapa Medium Tanam dan Konsentasi GA3. Buletin Agrohorti 1(1): 89-93.

Surya, M. I., Normasiwi, S., Ismaini, L., Kurniawan, V., and Putri, D. M. 2020. Pengaruh Berat Benih terhadap Perkecambahan dan Pertumbuhan Semai Biwa (Eriobotrya japonica Lind1.). Jurnal Perbenihan Tanaman Hutan 8(2): 79-90. DOI: 10.20886/bptpth.2020.8.2.79-90

Suprapto, A. 2014. Auksin: Zat Pengatur Tumbuh Penting Meningkatkan Mutu Stek Tanaman. Jurnal Penelitian Inovasi 21(1): 81-90.

Supriyanto, and Fiona, F. 2010. Pemanfaatan Arang Sekam untuk Memperbaiki Pertumbuhan Semai Jabon (Anthocephalus cadamba (Roxb.) Miq) pada Medium Subsoil. Jurnal Silvikultur Tropika 1(1): 24-28.

Tarigan, M. S., Barus, A., and Manik, F. 2014. Respons Pemberian Pupuk Organik Cair dan NPK Pada Tanaman Biwa (Eriobotrya Japonica Lindl.) di Main Nursery. Jurnal Online Agroekoteknologi 2(3): 547-560. DOI: 10.32734/jaet.v3i1.6980

Tarigan, R., and Barus, S. 2014. Teknik Perbanyakan Biwa (Loquat) Melalui Stek Pucuk. Iptek Hortikultura 10: 36-39. 
Taryana, Y., and Sugiarti, L. 2019. Pengaruh Medium Tanam terhadap Perkecambahan Benih Kopi Arabika (Coffea arabica L). Jurnal Agrosains dan Teknologi 4(2): 64-69.

Tian, S., Li, B., and Ding, Z. 2007. Physiological Properties and Storage Technologies of Loquat Fruit. Fresh Produce 1: 76-81.

Vilanova, S., Badenes, M. L., Martínez-Calvo, J., and Llácer, G. 2001. Analysis of Loquat Germplasm (Eriobotrya japonica Lindl) by RAPD Molecular Markers. Euphytica 121(1): 25-29. DOI: 10.1023/a:1012051207948

Zhang, W., Zhao, X., Sun, C., Li, X., and Chen, K. 2015. Phenolic Composition from Different Loquat (Eriobotrya japonica Lindl.) Cultivars Grown in China and Their Antioxidant Properties. Molecules 20: 542-555. DOI: 10.3390/molecules20010542 